RASĀYAN J. Chem.

Vol. 13 | No. 1 |354 - 362| January - March | 2020 ISSN: 0974-1496 | e-ISSN: 0976-0083 | CODEN: RJCABP http://www.rasayanjournal.com http://www.rasayanjournal.co.in

\title{
ELECTROPHORETIC DEPOSITION OF ZIRCONIA ON ALUMINA FOR MOLTEN SALT APPLICATIONS
}

\author{
A. Sheik Mideen ${ }^{1, *}$, G. Venkatasubramanian², T.M. Sridhar ${ }^{3}$ \\ and S. Vasudevan ${ }^{4}$ \\ ${ }^{1}$ Department of Chemistry, Sathyabama Institute of Science and Technology, Deemed to be \\ University, Chennai-600119, Tamilnadu, India \\ ${ }^{2}$ Department of Chemistry, Jeppiaar Mamallan Engineering College, \\ Vadamangalam-602108, Tamilnadu, India \\ ${ }^{3}$ Department of Analytical Chemistry, University of Madras, \\ Chennai-600025, Tamilnadu, India \\ ${ }^{4}$ Electroinorganic Division, Central Electrochemical Research Institute, \\ Karaikudi-602009, Tamilnadu, India \\ *E-mail: sheikmideen.chemistry@sathyabama.ac.in
}

\begin{abstract}
Electrophoretic deposition of zirconia on alumina crucibles was carried out at constant voltage conditions from zirconia suspension prepared with isopropyl alcohol. The phase purity and surface morphology of coated samples were characterized by X-ray diffraction, Fourier transform infrared spectroscopy and scanning electron microscopy coupled with energy dispersive X-ray analysis. The maximum deposit yield was obtained with a direct current potential of $125 \mathrm{~V}$. The substrates pretreated with acid-base and subjected for sintering temperature $1100^{\circ} \mathrm{C}$ for one hour showed excellent adhesion on both sides. The X-ray diffraction results showed the monoclinic phase is the major component and the average crystallite sizes of coated deposits were found as $\sim 4.1 \mu$. The absorption bands observed at $463 \mathrm{~cm}^{-1}, 743 \mathrm{~cm}^{-1}$ and at $486 \mathrm{~cm}^{-1}$ confirm the presence of $\mathrm{ZrO}_{2}$ phases. The intensity of bands observed at $3415 \mathrm{~cm}^{-1}$ and $1634 \mathrm{~cm}^{-1}$ were gradually decreased due to sintering confirm the stretching and deformation of the $\mathrm{O}-\mathrm{H}$ bond. The surface analysis showed that the zirconia particles are of uniform size and there is a considerable agglomeration of the particles on alumina substrates. The energy dispersive analysis indicated the presence of elemental $\mathrm{Zr}$ and $\mathrm{O}$ and sintering causes the penetration of agglomerated zirconia particles into the micropores present on alumina substrates and is responsible for excellent adhesion.

Keywords: Electrophoretic Deposition, Zirconia Deposits, Alumina Crucibles, Sintering, XRD, FTIR, SEM.
\end{abstract}

(C) RASĀYAN. All rights reserved

\section{INTRODUCTION}

Electrophoretic deposition (EPD) is a convenient method of producing uniform deposition of ceramics and composite materials ${ }^{1-3}$ within a short time interval and at low cost on various substrates. In EPD, it is generally believed that particles migrate toward the oppositely charged electrode under the effect of an electric field and when they reach the surface of the substrate, the repulsive potential between the particles is reduced in turn the particles coagulate because of van der Waals attraction and get deposited on the substrate. The major parameters for processing of ceramic particles in EPD are the preparation of suspensions and application methods of the electric fields that affect the microstructure of deposits. ${ }^{1,4-5}$ EPD is mostly performed in non-aqueous suspensions of either alcohol or ketone or a mixture of them. The main advantage of non-aqueous media for EPD is the possibility to use high voltages and consequently to obtain higher deposition rates. ${ }^{3-7}$

Since molten uranium metal reacts with a graphite crucible, a challenge in the pyrochemical technique is to use crucible coatings which include zirconia $\left(\mathrm{ZrO}_{2}\right)$, magnesia $(\mathrm{MgO})$ and yttria $\left(\mathrm{Y}_{2} \mathrm{O}_{3}\right){ }^{8}$ Different

Rasayan J. Chem., 13(1), 354-362(2020)

http://dx.doi.org/10.31788/RJC.2020.1315512

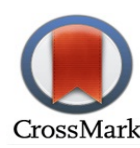


RASĀYAN J. Chem.

Vol. 13 | No. 1 |354 - 362| January - March | 2020

techniques have been used for the preparation of ceramic coatings on high-density graphite crucibles. The most promising methods are plasma spraying for zirconia diffusion barrier coatings in nuclear reactors ${ }^{9}$, laser remelting to eliminate microstructural inhomogeneities like pores and voids present in the partially stabilized zirconia (PSZ) coating and to obtain a smooth and dense layer ${ }^{10}$, physical vapor deposition (PVD) of nitride coatings for uranium melting applications in cathode processor. ${ }^{11}$ However, these methods are generally complicated, time-consuming and also expensive for large scale production in the industry. Accordingly, a suitable ceramic material must be selected which does not react with uranium and must be used as a coating material on the ceramic crucible surface.

In this work, the cost-effective EPD technique is used to produce a homogeneous and adherent deposit of zirconia on alumina crucibles to provide adequate protection at the temperatures normally required for melting uranium alloys.

\section{EXPERIMENTAL}

Figure-1 shows the photograph of electrophoretic deposition set up used for the deposition of zirconia powder on alumina substrate.

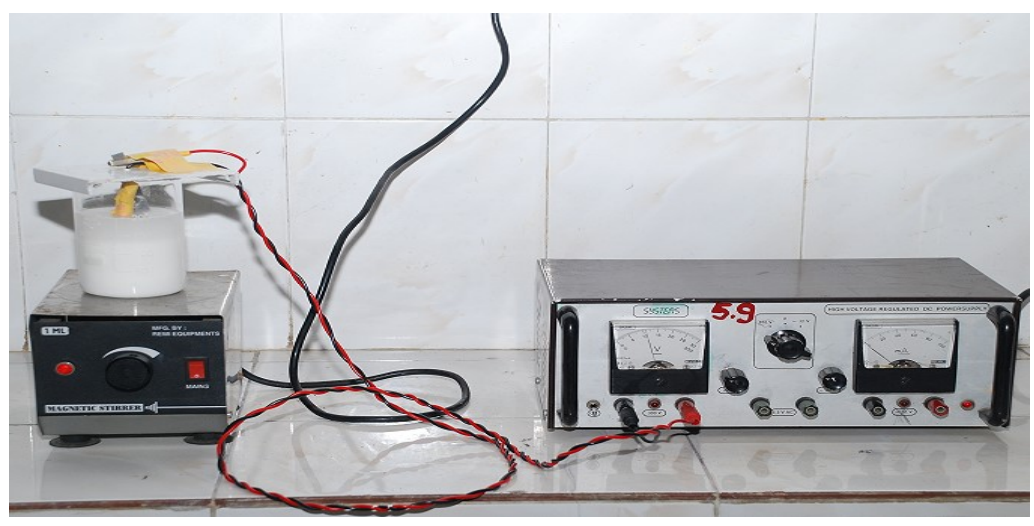

Fig.-1: Experimental Setup for Electrophoretic Deposition

The electrophoretic deposition was carried out at a constant voltage condition using a DC power supply [SYSTEMS High Voltage Regulated DC Power Supply, 0-300 V] from suspensions of zirconia powder [SDFCL, 98.5\% pure] prepared with isopropyl alcohol [SDFCL, 99.5\% pure]. The applied voltage was fixed at 30,50,75,100,125 and 150 Volts. The parameter time was also varied from 10 to 30 minutes for the deposition. ${ }^{12-15}$ A stainless steel sheet with a working area of $100 \times 50 \mathrm{~mm}^{2}$ was used as the anode. Alumina crucible samples were used as a working electrode (cathode). The samples were polished with different grids of emery sheets and finally degreased with acetone. The distance between the cathode and anode was fixed at $10-15 \mathrm{~mm}$. The experiments were conducted under stirring conditions using a magnetic stirrer [REMI make]. The deposited weights were measured by weighing the alumina substrates before and after deposition and drying in air at room temperature.

Since the cells used for electro refining and cathode processes are operated at about $450-500^{\circ} \mathrm{C}$, after EPD process the sintering of green deposits were carried out in a muffle furnace using a heating rate of $10^{\circ} \mathrm{C} \mathrm{min}^{-1}$ up to $600^{\circ} \mathrm{C}$ and hold it for 2 hours. Then the samples were furnace cooled to room temperature. The phases present after sintering were identified by powder XRD using CuK $\alpha$ radiation. The sintered microstructure was studied by SEM (JEOL JSM5410). The composition of the sintered samples was studied by EDX.

Further, in order to improve coating adhesion on alumina crucibles (i) one set of samples were pretreated by heating to a temperature $400^{\circ} \mathrm{C}$ for 1 hour (ii) the second set of samples were subjected to acid-base treatment (immersing the samples in $5 \% \mathrm{NaOH}$ for 30 seconds in $5 \% \mathrm{HCl}$ solution for 30 seconds successively for ten times with intermediate rinsing in deionized water to remove organic contaminants ${ }^{16}$ before coating. Then the optimized bath parameters were used for zirconia coating on alumina substrates. The coated samples were subjected to various sintering temperatures namely $800^{\circ} \mathrm{C}$ and $1100^{\circ} \mathrm{C}$ for one hour at the rate of $15^{\circ} \mathrm{C}$ per minute in a muffle furnace. 
RASĀYAN J. Chem.

Vol. 13 | No. 1 |354 - 362| January - March | 2020

Phase analyses of coated samples before sintering and after sintering were performed on an X-ray diffractometer (PANalytical-Make), X'per PRO-Model, by using monochromatic $\mathrm{CuK} \alpha$ radiation. Samples are scanned in a continuous mode from $20^{\circ}-80^{\circ}$ with a scanning rate of 0.02 (degree) $\mathrm{sec}^{-1}$. The identification of phases was carried out by comparison of XRD patterns with JCPDS standards. FTIR spectra of the zirconia powder as received, before and after sintering at $600^{\circ} \mathrm{C}$ for 2 hours in $\mathrm{KBr}$ pellets were studied in the range of $400-4000 \mathrm{~cm}^{-1}$ by using IR-spectrometer [Thermo Electron Corporation, USA-Make, Nexus 670 (FTIR), Centaurms 10X (Microscope)-Model, Detector: DTGS (KBr window) (deuterated triglycine sulfate); Spectral Range 11,000 to $375 \mathrm{~cm}^{-1}$; Beam splitter-XT-KBr].

The surface morphology of the samples was characterized by conventional scanning electron microscopy (JEOL JSM 5410 SEM). The powder samples were embedded in a conductive graphite adhesive fixed to an aluminium stub and then gold-coated with a Polaron E5000 sputter-coating unit for 2 minutes. The composition and purity of the sintered samples were studied by EDX.

\section{RESULTS AND DISCUSSION}

The weight of deposit yield versus the applied potential (30V to $150 \mathrm{~V})$ from the different concentration of zirconia suspension in isopropyl alcohol (IP) with 10 minutes duration is shown in Fig.-2. The increase in weight of the deposit was found to increase with applied potential up to $100 \mathrm{~V}$. Further increase of applied potential resulted in a decrease in the weight deposit. However, the maximum weight of deposit was higher when the potential was applied to $125 \mathrm{~V}$ from the zirconia concentration of $10 \%$ by weight and then resulted in a decrease in weight deposit.

The amount of deposit yield from the different concentration of zirconia suspension in isopropyl alcohol ( $3 \%$ by weight to $15 \%$ by weight) by varying the applied potential of $30 \mathrm{~V}$ to $150 \mathrm{~V}$ for 10 minutes time is shown in Fig.-3. It was found that the electrophoretic deposition rate with the applied potentials gradually increases with the increase of concentration of zirconia in isopropyl alcohol. The maximum deposit yield of $4.3754 \mathrm{mg} . \mathrm{cm}^{-2}$ was observed at $125 \mathrm{~V}$ from the suspension of $10 \%$ by weight zirconia. Further increase in concentration resulted in a decrease in mass yield.

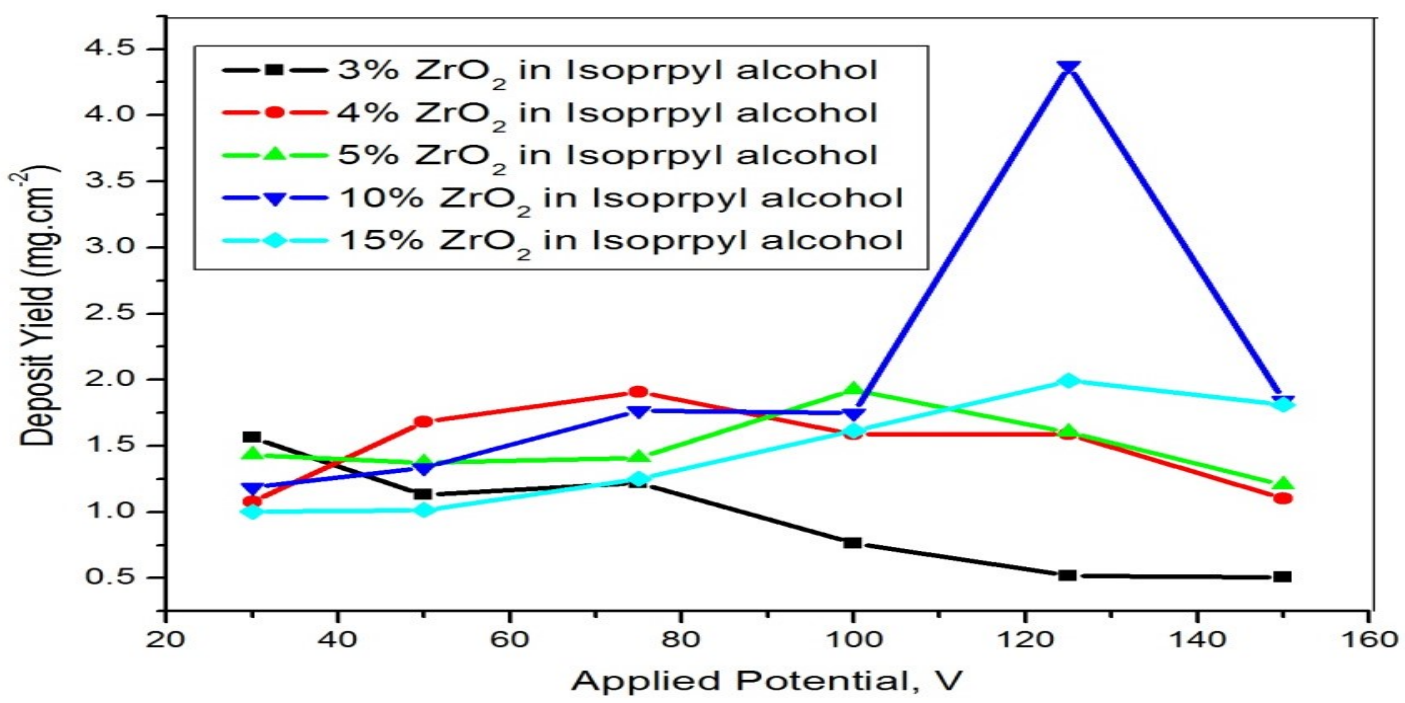

Fig.-2: Applied Potential Vs Deposit Yield

The deposit yield versus the duration of deposition at the optimized applied potentials with varying concentrations of the electrolyte is shown in Fig.-4. The relation between the deposit weight and the deposition time was linear up to 30 minutes for the concentrations $3 \%$ by weight and $4 \%$ weight of zirconia in isopropyl alcohol suspension. But the deposition time was non-linear for higher concentrations of $10-15 \%$ by weight and then the deposition rate was gradually slowed down with time. The maximum deposit yield of $5.154 \mathrm{mg} \mathrm{cm}^{-2}$ was observed at 20 minutes time from the suspension of $10 \%$ by weight zirconia at $125 \mathrm{~V}$. Further increase of time resulted in a decrease in mass yield. 
RASĀYAN J. Chem.

Vol. 13 | No. 1 |354 - 362| January - March | 2020

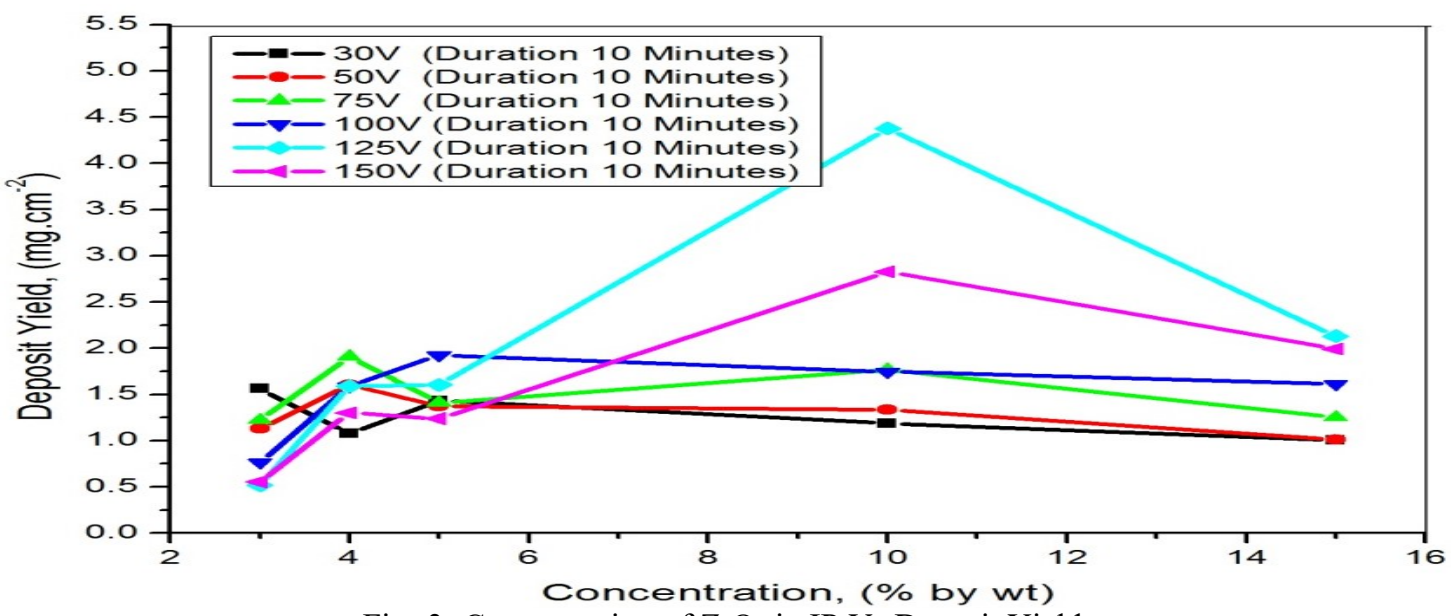

Fig.-3: Concentration of $\mathrm{ZrO}_{2}$ in IP Vs Deposit Yield

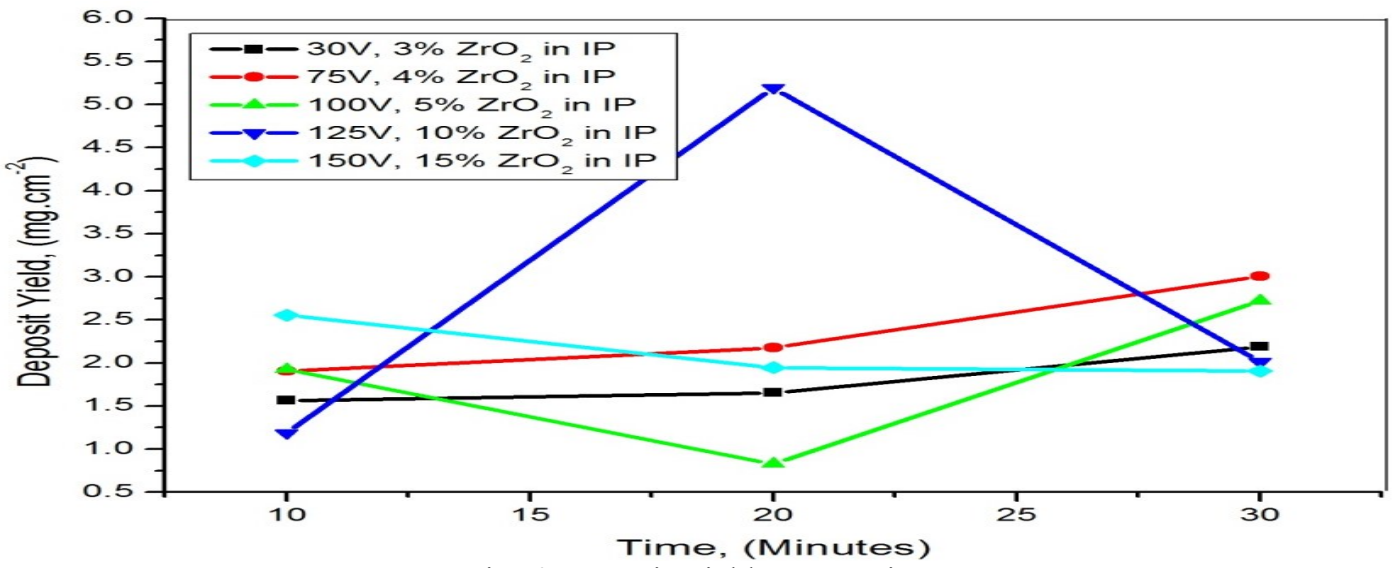

Fig.-4: Deposit Yield Vs Duration

Based on the various optimized bath parameters for electrophoretic deposition of zirconia on alumina crucibles, the maximum deposit yield of $5.154 \mathrm{mg} \mathrm{cm}$ was observed at 20 minutes time from the suspension of $10 \%$ by weight zirconia at $125 \mathrm{~V}$.

The sintering of green deposits was carried out in a muffle furnace using a heating rate of $10-15^{\circ} \mathrm{C} \min ^{-1}$ at various temperatures. Since the cells used for electrorefining and cathode processes are operated at about $450-500^{\circ} \mathrm{C}^{5}$, the sintering of zirconia coated alumina samples were first carried out at $600^{\circ} \mathrm{C}$ for 2 hours. But the coated samples showed poor adhesion. In order to improve coating adhesion, various pretreatment methods were adopted and sintering with different temperatures was done (Table-1). The samples pretreated with acid-base treatment with sintering temperatures $800^{\circ} \mathrm{C}$ and $1100^{\circ} \mathrm{C}$ for one hour showed excellent adhesion on both the sides of samples. But micro-cracks have been observed on inner walls of crucibles due to settling of zirconia by stirring when sintering was done at $800^{\circ} \mathrm{C}$. However, due to the penetration of zirconia into the micropores at $1100^{\circ} \mathrm{C}$, the micro-cracks present in the substrate vanished both on the inner surface as well as the outer surface of the samples. A solution of hexafluorozirconic acid in the presence of $\mathrm{Co}$ (II) and Ni (II) ions has been developed for improving the adhesion strength of zirconium oxide coatings on the surface of iron. ${ }^{17}$

From the Fig.-5, it can be seen that the $\mathrm{ZrO}_{2}$ powder contains two crystalline phases. The major peak observed at $2 \theta=28.2^{\circ}$ indicates the monoclinic phase. ${ }^{18}$ Another major peak with the highest intensity $2 \theta$ $=31.3^{\circ}$ indicates the tetragonal phase. ${ }^{19}$ The relative amount of monoclinic zirconia was determined according to the polymorph method recommended by Garvie and Nicholson from the integral intensities

of two monoclinic peaks ${ }^{20} I_{m}(111)$ and $I_{m}(111)$ and one tetragonal peak $I_{t}(111)$. The equation for the monoclinic phase is: 
RASĀYAN J. Chem.

Vol. 13 | No. 1 |354 - 362| January - March | 2020

$$
X_{m}=\frac{I_{m}(111)+I_{m}(11 \overline{1})}{I_{m}(111)+I_{m}(11 \overline{1})+I_{t}(111)} \times 100
$$

where $X_{t}$ and $X_{m}$ stand for the weight percentage of the tetragonal and monoclinic phases respectively, whereas $I_{t}$ and $I_{m}$ are the intensities of their diffraction peaks.

Table-1: Optimization of Pretreatment Methods and Sintering Temperature to Improve Adhesion of Zirconia on

\begin{tabular}{|c|c|c|c|c|}
\hline S. No. & $\begin{array}{l}\text { Type of Pretreatment Done } \\
\text { on a Sample }\end{array}$ & $\begin{array}{c}\text { Sintering } \\
\text { Temperature }\end{array}$ & Duration & Observation \\
\hline 1. & $\begin{array}{l}\text { Polished with different } \\
\text { grids of emery sheets and } \\
\text { degreased with acetone. }\end{array}$ & $600^{\circ} \mathrm{C}$ & 2 hours & $\begin{array}{l}\text { Showed poor coating adhesion on } \\
\text { both the sides of coated samples. }\end{array}$ \\
\hline 2. & $\begin{array}{l}\text { Polished with different } \\
\text { grids of emery sheets and } \\
\text { degreased with acetone. }\end{array}$ & $800^{\circ} \mathrm{C}$ & 1 hour & $\begin{array}{l}\text { Showed improved adhesion on both } \\
\text { the sides of samples. But micro- } \\
\text { cracks have been observed on the } \\
\text { inner walls of crucibles due to the } \\
\text { settling of zirconia by stirring. }\end{array}$ \\
\hline 3. & $\begin{array}{c}\text { Subjected to } 400^{\circ} \mathrm{C} \text { for one } \\
\text { hour }\end{array}$ & $800^{\circ} \mathrm{C}$ & 1 hour & $\begin{array}{l}\text { Showed improved adhesion on both } \\
\text { the sides of samples. But micro- } \\
\text { cracks have been observed on the } \\
\text { inner walls of crucibles due to the } \\
\text { settling of zirconia by stirring. }\end{array}$ \\
\hline 4. & Acid-base treatment & $800^{\circ} \mathrm{C}$ & 1 hour & $\begin{array}{l}\text { Showed excellent adhesion on both } \\
\text { the sides of samples. But micro- } \\
\text { cracks have been observed on the } \\
\text { inner walls of crucibles due to the } \\
\text { settling of zirconia by stirring. }\end{array}$ \\
\hline 5. & Acid-base treatment & $1100^{\circ} \mathrm{C}$ & 1 hour & $\begin{array}{l}\text { Showed excellent adhesion on both } \\
\text { the sides of samples. }\end{array}$ \\
\hline
\end{tabular}
Alumina Samples

By comparing the intensities of these two crystalline phases, we can conclude that the monoclinic phase is the major component in the powder mixture and the calculated ratio for the monoclinic to tetragonal phases is $6.5: 1$. The average crystallite sizes were estimated by the Scherrer equation using the full width at half maximum (FWHM) of the most intense peak(111). As reported in the literature ${ }^{21-22}$, Scherrer's equation is described as:

$$
D=\frac{k \lambda}{B \cos \theta}
$$

Where, $D$ is the average crystallite size or particle size, $k$ is a constant (shape factor, about 0.9 ), $\lambda$ is the wavelength of X-ray wavelength radiation $(0.1540593 \mathrm{~nm}$ or $1.54056 \AA), \theta$ is the Bragg diffraction angle and $B$ is the full width at half maximum (FWHM) of the diffraction line (FWHM). The average crystallite size of zirconia sample lies in the range of $\sim 4.1 \mu \mathrm{m}$. Further, the sintering temperature has no effect on the average crystallite size of zirconia particles.

Fourier transform infrared spectroscopy (FTIR) analysis of commercial zirconia powder as received, green deposit and after sintering at $1100^{\circ} \mathrm{C}$ for 1 hour were carried out in the wavenumber range 400 $4000 \mathrm{~cm}^{-1}$ (Fig.-6).

For this analysis, $\mathrm{KBr}$ pellets were pressed to hold the samples to be analyzed. The bands at $3415 \mathrm{~cm}^{-1}$ and $1634 \mathrm{~cm}^{-1}$ correspond to the vibration of stretching and deformation of the $\mathrm{O}-\mathrm{H}$ bond due to the absorption of water and coordination water, respectively. After sintering, the intensity of these bands 
RASĀYAN J. Chem.

Vol. 13 | No. 1 |354 - 362| January - March | 2020

gradually decreased. Another important absorption band observed at $463 \mathrm{~cm}^{-1}$, which is related to the vibration of the $\mathrm{Zr}-\mathrm{O}$ bond in $\mathrm{ZrO}_{2}{ }^{23}$ The IR spectra of zirconia samples also showed the various stretching frequencies at $541 \mathrm{~cm}^{-1}, 596 \mathrm{~cm}^{-1}$, and $1116 \mathrm{~cm}^{-1}$ respectively as reported earlier. ${ }^{24}$ The features particularly at $743 \mathrm{~cm}^{-1}$ is due to $\mathrm{Zr}-\mathrm{O}_{2}-\mathrm{Zr}$ asymmetric and at $486 \mathrm{~cm}^{-1}$ is due to $\mathrm{Zr}-\mathrm{O}$ stretching mode, confirm the presence of $\mathrm{ZrO}_{2}$ phases. ${ }^{25-27}$

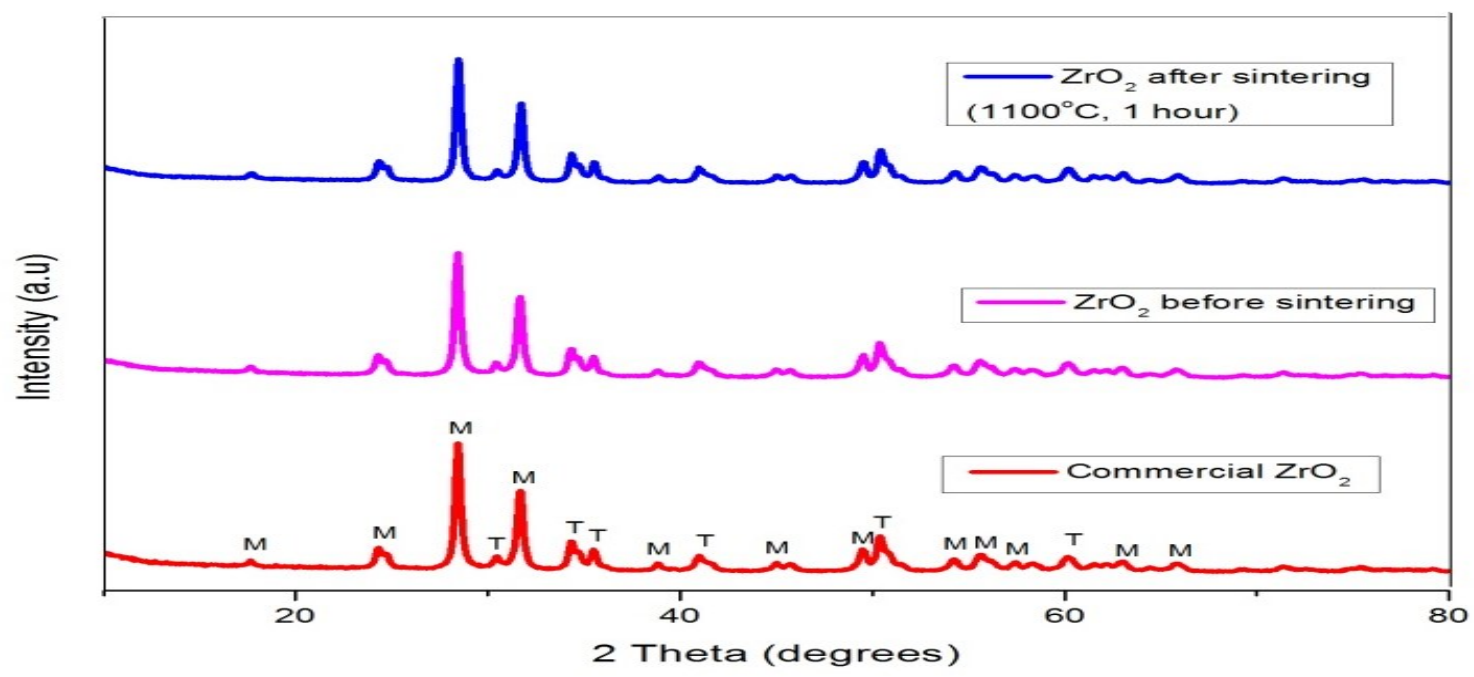

Fig.-5: XRD Pattern of Commercial $\mathrm{ZrO}_{2}$ (Red); Before Sintering (Magenta), and After Sintering at $1100^{\circ} \mathrm{C}$ for One Hour (Blue)

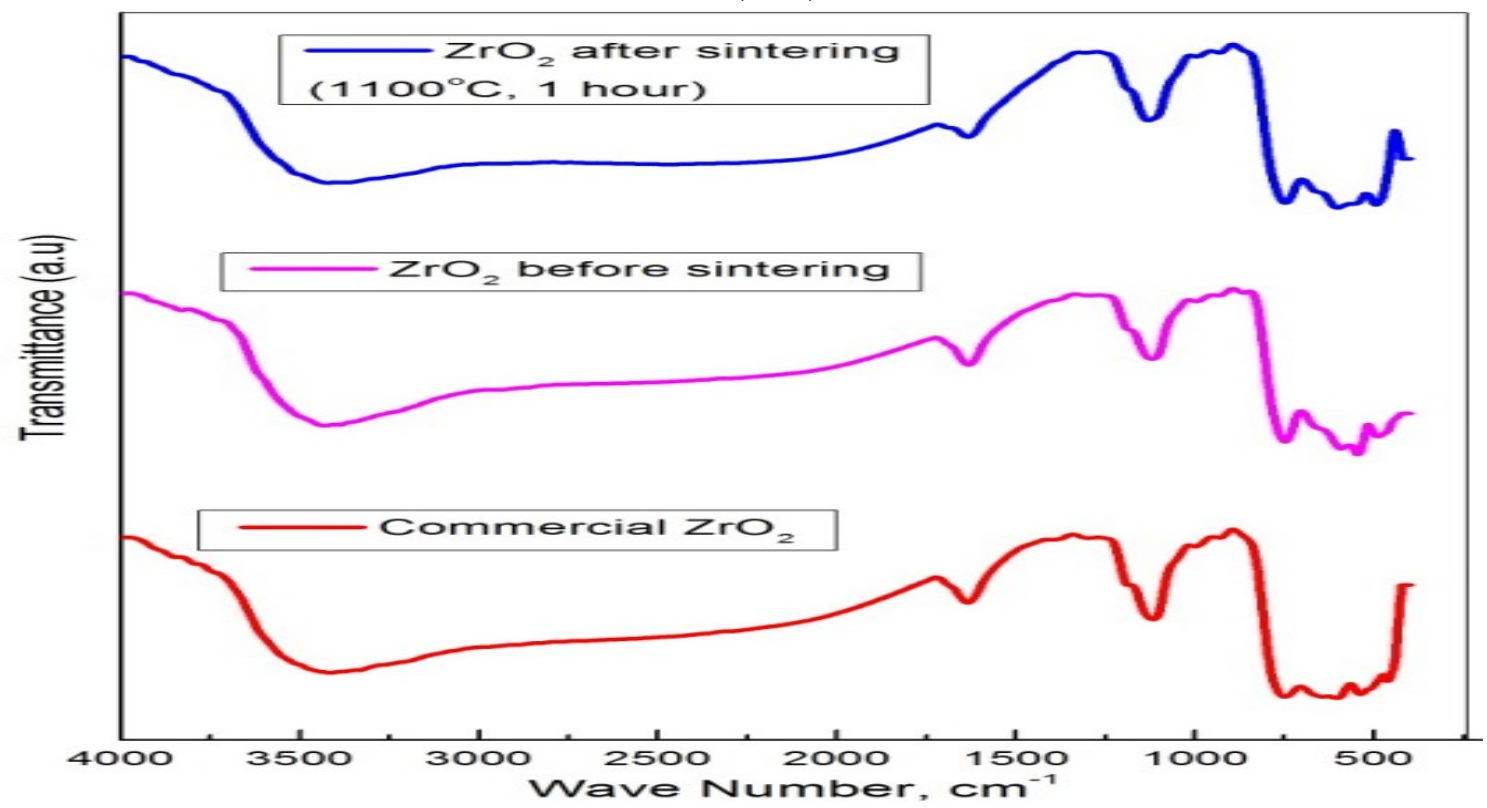

Fig.-6: FTIR Curves of Commercial $\mathrm{ZrO}_{2}$ (Red); Before Sintering (Magenta), and After Sintering at $1100^{\circ} \mathrm{C}$ for One Hour (Blue)

The SEM-EDX analyses were done for zirconia coated alumina samples before and after sintering. Fig.$7 \mathrm{a}$ and Fig.-7b show the SEM and the EDX profile of the zirconia coated sample before sintering. The zirconia particles are of uniform size; however, there is a considerable agglomeration of the particles along the substrate. The EDX analysis indicates the presence of elemental $\mathrm{Zr}$ and $\mathrm{O}$ in the sample with a relative proportion corresponding to the $\mathrm{ZrO}_{2}$ particles. It also showed the presence of coated zirconia on the substrate is of $100 \%$ purity. Fig.-8a and Fig.-8b show the SEM and the EDX profile of the zirconia coated sample after sintering at $1100^{\circ} \mathrm{C}$ for one hour. Sintering causes the segregation of agglomerated 
RASĀYAN J. Chem.

Vol. 13 | No. 1 |354 - 362| January - March | 2020

zirconia particles on the alumina surface. This caused penetration of zirconia into the micro pores present in the substrate and the result corresponds well with the FTIR results of samples where the presence of the peak $491 \mathrm{~cm}^{-1}$ corresponds to $\mathrm{Zr}-\mathrm{O}$ vibration. Further, EDX analysis showed the coated purity of zirconia particles remains as $100 \%$.

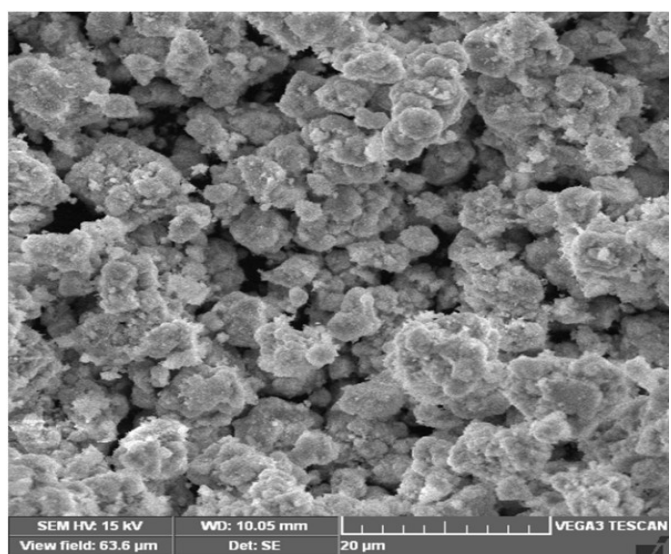

Fig.-7a: The SEM Micrograph of Zirconia Coated Alumina Sample
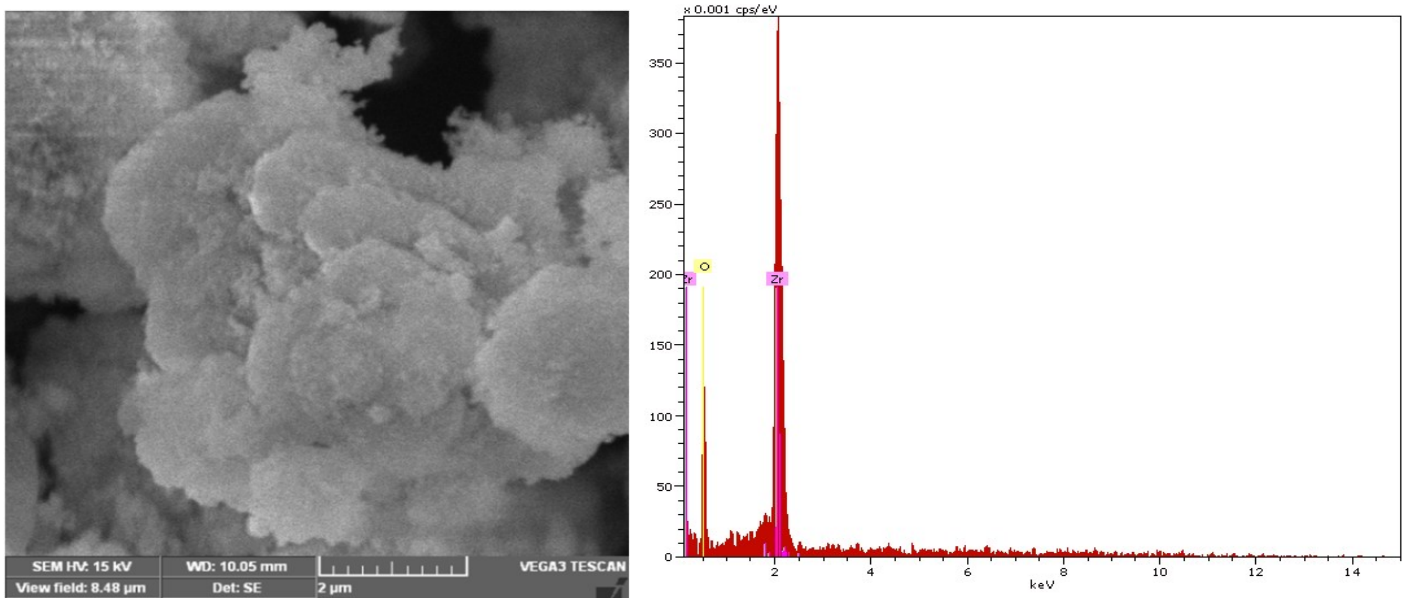

Fig.-7b: The SEM Micrograph and EDX Pattern of Zirconia Coated Alumina Sample

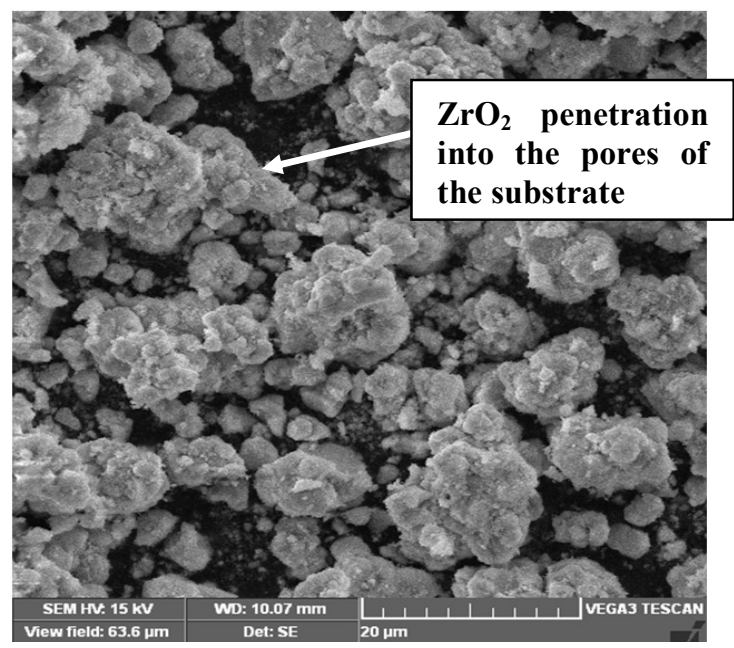

Fig.-8a: The SEM Micrograph of Zirconia Coated Alumina Sample after Sintering at $1100^{\circ} \mathrm{C}$ for One Hour 
RASĀYAN J. Chem.

Vol. 13 | No. 1 |354 - 362| January - March | 2020
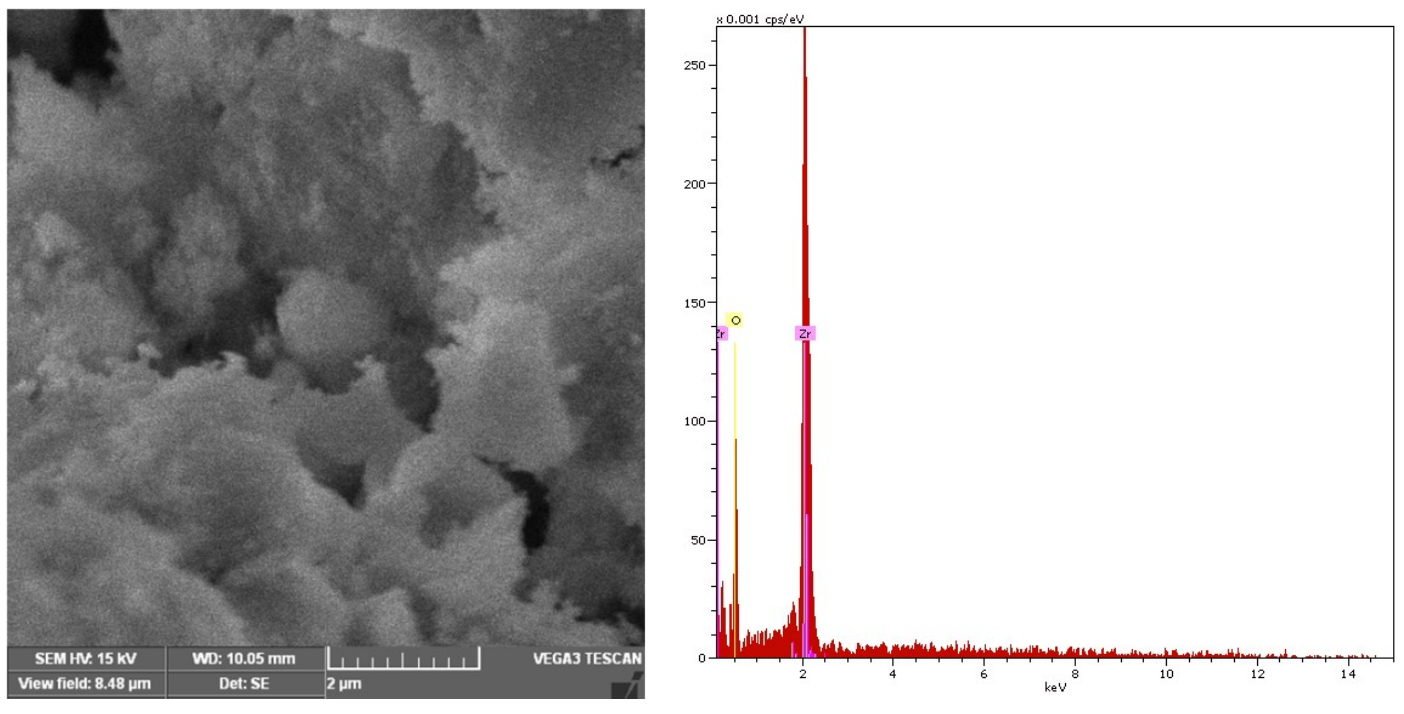

Fig.-8b: The SEM Micrograph and EDX Pattern of Zirconia Coated Alumina Sample after Sintering at $1100^{\circ} \mathrm{C}$ for One Hour

\section{CONCLUSION}

Bath parameters have been optimized for electrophoretic deposition of zirconia on alumina crucibles. The samples pretreated with acid-base treatment with sintering temperature $1100^{\circ} \mathrm{C}$ for a one-hour duration showed excellent adhesion on both the sides of samples. The average crystallite sizes of coated deposits were found as $\sim 4.1 \mu$. The phase purity of the zirconia sample showed that the existence of both $\mathrm{m}-\mathrm{ZrO}_{2}$ and $\mathrm{t}-\mathrm{ZrO}_{2}$. The FTIR studies further confirm the presence of $\mathrm{ZrO}_{2}$ phases. The SEM analysis showed that the zirconia particles are of uniform size and there is considerable agglomeration of the particles on alumina substrates. The energy dispersive X-ray (EDX) analysis further confirmed that the sintering causes the penetration of agglomerated zirconia particles into the micropores present on alumina samples and is responsible for excellent adhesion.

\section{ACKNOWLEDGEMENT}

The authors would like to express their sincere thanks to Dr. Mariazeena Johnson, Chancellor, and Dr. Marie Johnson, President, Sathyabama Institute of Science and Technology for their encouragement in writing this paper. The authors would also like to express their sincere thanks to Dr. U. Kamatchi Mudali, Distinguished Scientist and Chairman \& Chief Executive of Heavy Water Board (HWB) for his valuable suggestions for carrying out the experiments and for fruitful discussions.

\section{REFERENCES}

1. O.O. Van der Biest, L.J. Vandeperre, Annual Review of Materials Science, 29, 327(1999), DOI: 10.1146/annurev.matsci.29.1.327

2. J.W. Koger, C.E. Holcombev, J.G. Banker, Thin Solid Films, 39, 297(1976), DOI: 10.1016/00406090(76)90649-0

3. X.Q. Cao, R. Vassen, D. Stoever, Journal of the European Ceramic Society, 24(1), 1(2004), DOI: 10.1016/S0955-2219(03)00129-8

4. A. Ravi Shankar, U. Kamachi Mudali, S. Ravikumar, H.S. Khatak, Baldev Raj, Journal of Nuclear Materials, 372(2-3), 226(2008), DOI: 10.1016/j.jnucmat.2007.03.216

5. A.R. Boccaccini, I. Zhitomirsky, Current Opinion in Solid State Materials Science, 6(3), 251(2002), DOI: $10.1016 / \mathrm{S} 1359-0286(02) 00080-3$

6. S.N. Heavens, 1990, Electrophoretic Deposition as a Processing Route for Ceramics, In: Jon G.P. Biner (Ed.), Advanced Ceramic Processing and Technology, 1, Park Ridge, NJ: Noyes Pub., pp. 255283. 
RASĀYAN J. Chem.

Vol. 13 | No. 1 |354 - 362| January - March | 2020

7. I. Zhitomirsky, Advances in Colloid Interface Science, 97(1-3), 279(2002), DOI:10.1016/S00018686(01)00068-9

8. F.F. Lange, Journal of the American Ceramic Society, 72(1), 3(1989), DOI:10.1111/j.11512916.1989.tb05945.x

9. F. Tang, T. Uchikoshi, K. Ozawa, Y. Sakka, Journal of the European Ceramic Society, 26(9), 1555(2006), DOI:10.1016/j.jeurceramsoc.2005.03.240

10. X. Zhu, T. Uchikoshi, T.S. Suzuki, Y. Sakka, Journal of the American Ceramic Society, 90(3), 797(2007), DOI: $10.1111 / \mathrm{j} .1551-2916.2007 .01491 . x$

11. M. Iijima, H. Kamiya, KONA Powder and Particle Journal, 27, 119(2009), DOI: 10.14356/kona.2009012

12. J. Cihlar, D. Drdlik, Z. Cihlarova, H. Hadraba, Journal of the European Ceramic Society, 33(10), 1885(2013), DOI: 10.1016/j.jeurceramsoc.2013.02.017

13. H. Maleki-Ghaleh, M. Rekabeslami, M.S. Shakeri, M.H. Siadati, M. Javidi, S.H. Talebuan, H. Aghajani, Applied Surface Science, 280, 666(2013), DOI: 10.1016/j.apsusc.2013.04.173

14. H. Amiri, I. Mohammadi, A. Afshar, Surface and Coatings Technology, 311, 182(2017), DOI: 10.1016/j.surfcoat.2016.12.103

15. F. Saberi, B.S. Boroujeny, A. Doostmohamdi, A. R. Baboukani, M. Asadikiya, Materials Chemistry and Physics, 213, 444(2018), DOI: 10.1016/j.matchemphys.2018.04.050

16. R. H. J. Hannink, P. M. Kelly, B.C. Muddle, Journal of the American Ceramic Society, 83(3), 461(2000), DOI: 10.1111/j.1151-2916.2000.tb01221.x

17. M. Zh. Zhurinov, V.N. Statsyuk, L.A. Fogel1, A. Bold, A.A. Abrashov, A. Kostiuk, Rasayan Journal of Chemistry, 12(3), 1287(2019), DOI:10.31788/RJC.2019.1235205

18. Joint Committee on Powder Diffraction Standards. Diffraction Data File No. 37-1484, ICDD, Newtown Square, PA, 2001.

19. Joint Committee on Powder Diffraction Standards. Diffraction Data File No. 42-1164, ICDD, Newtown Square, PA, 2001.

20. R. C. Garvie, P. S. Nicholson, Journal of the American Ceramic Society, 55(6), 303(1972), DOI: 10.1111/j.1151-2916.1972.tb11290.x

21. P. Scherrer, Göttinger Nachrichten Gesellschaft German, 2 (1918) 98

22. C. Ribeiro, C. Vila, J.M.E. de Matos, J. Bettini, E. Longo, E.R. Leite, Chemistry A European Journal, 13(20), 5798(2007), DOI: 10.1002/chem.200700034

23. Y. Hao, J. Li, X. Yang, R.D. Hunt, Materials Science Engineering A, 367(1-2), 243(2004), DOI: 10.1016/j.msea.2003.10.321

24. D.A. Powers, H.B. Gray, Inorganic Chemistry, 12(11), 2721(1973), DOI: 10.1021/ic50129a045

25. S.W. Lee, R. A. Condrate Sr, Journal of Materials Science, 23(8), 2951(1988), DOI: 10.1007/BF00547474

26. F. del Monte, W. Larsen, J. D. Mackenzie, Journal of the American Ceramic Society, 83(3), 628(2000), DOI: 10.1111/j.1151-2916.2000.tb01243.x

27. R. N. Viswanath, S. Ramasamy, Journal of Materials Science, 34(12), 2879(1999), DOI: 10.1023/A:1004639519563

[RJC-5512/2019] 